\title{
The Effects of Japanese Foreign Exchange Intervention \\ GARCH Estimation and Change Point Detection ${ }^{1}$
}

\author{
ERIC HILLEBRAND \\ Department of Economics, Louisiana State University, Baton Rouge, LA 70803, USA, \\ Tel. +1 2255783795 , FAX. +1 2255783807 \\ erhil@1su.edu
}

\begin{abstract}
GUNTHER SCHNABL
Department of Economics and Business Administration, Tübingen University, Nauklerstraße 47, 72070 Tübingen, Germany, Tel. +49 70712974145 FAX. +49 707129 5077,

gunther.schnabl@uni-tuebingen.de
\end{abstract}

May 72004

\begin{abstract}
We study the impact of Japanese foreign exchange intervention on the volatility of the yen/dollar exchange rate since the early 1990s. Using daily intervention data provided by the Japanese Ministry of Finance, we show that the success of interventions varies over time. Measured on the total sample between 1991 and 2003 the estimation results for the impact of foreign exchange intervention on the yen/dollar exchange rate volatility are inconclusive. Sub-dividing the sample into yearly sub-periods and into intervention clusters suggests a structural break. From 1991 up to the late 1990s Japanese foreign exchange intervention seems to have increased the volatility of the yen/dollar exchange rate. In contrast in the new millennium, Japanese foreign exchange intervention is associated with less exchange rate volatility. Non-arbitrary segmentation by change point detection leads to similar results. The evidence in favour of recent successful Japanese foreign exchange intervention is line with theoretical evidence which implies successful intervention is the case of unsterilized intervention.
\end{abstract}

Keywords: Japan, Foreign Exchange Intervention, Exchange Rate Volatility, GARCH, Change Point Detection, Liquidity Trap.

JEL: E58, F31, F33, G15, C32

1 We thank Paul De Grauwe, Rishi Goyal, Kimie Harada, Ronald McKinnon and Magdalena Polan for useful comments. 


\section{Table of Contents}

1. INTRODUCTION 3

2. THEORETICAL AND EMPIRICAL BACKGROUND ............................................. 4

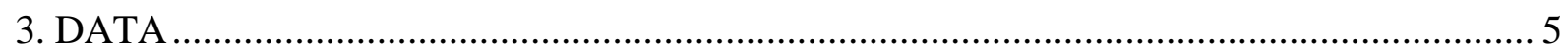

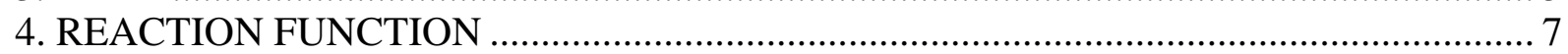

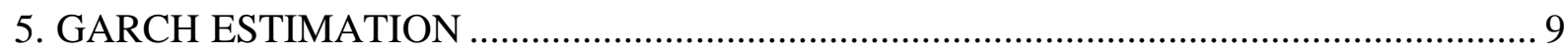

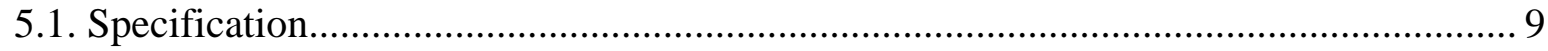

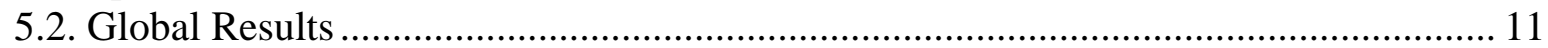

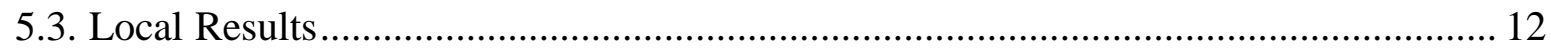

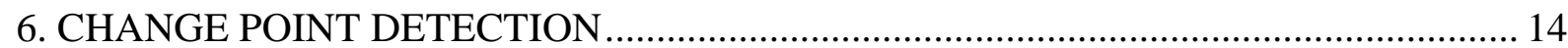

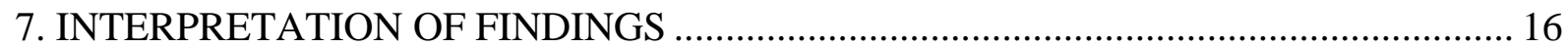




\section{INTRODUCTION}

Japan's persistent post-bubble blues is characterized by a combination of economic stagnation and a strong currency (Schnabl 2001). While real growth of Japanese GDP during the 1990s approached the zero bound, the exchange rate of the Japanese yen has been surprisingly strong. With the Japanese export sector remaining the most reliable pillar of the ailing economy, Japanese monetary authorities ${ }^{2}$ have been more and more tempted to sustain output by dollar purchases (Schwartz 2000). Japanese foreign exchange intervention has dwarfed official US official foreign currency transactions since the early 1990s, both in terms of single intervention events and in terms of cumulated intervention volume (Figure 1 and Figure 2).

\section{[Figure 1 and Figure 2 about here]}

With the sustained depression of the Japanese economy — and with fiscal and monetary policy at their limits many authors have proposed reviving the Japanese economy by even more (un-)sterilized foreign exchange intervention (McCallum, 2000 and Svensson, 2001). To determine the pros and cons of this policy proposition we scrutinize the impact of sterilized foreign exchange intervention on the volatility of the yen/dollar exchange rate.

In contrast to former studies, which were mostly based on perceived intervention reported by press and wires services, but following Ito (2002) we use newly revealed data on foreign exchange intervention (instead of dummy variables) for our inquiry. Frenkel, Pierdzioch and Stadtmann (2003) use the newly revealed data to examine the accuracy of former data sets on perceived intervention. They show the deviations of the data set by Ramaswamy and Samiei (2000) from the de facto data. Japan provides a particularly interesting case for studying the effects of foreign exchange intervention because intervention volumes are exceptionally high for a (more or less) freely floating currency.

A GARCH model with interventions as exogenous variables for mean and volatility is fitted to the institutional setting of Japanese foreign exchange intervention. To cope with possible bias caused by parameter changes during the observation period local coefficients for means and volatility are estimated. A change point detector provides non-arbitrary segments for local GARCH estimation. Finally, rolling GARCH( 1,1$)$ estimations give additional evidence on the structural break in the effects of Japanese foreign exchange intervention.

2 According to the Foreign Exchange and Foreign Trade Law (article 7, paragraph 3), the Ministry of Finance is in charge of Japanese foreign exchange intervention. The central bank acts solely as an agent (Article 36 and article 40; paragraph 2, Bank of Japan Law) and buys or sells foreign currency on the government's account. 


\section{THEORETICAL AND EMPIRICAL BACKGROUND}

The discussion about the effectiveness of foreign exchange intervention has been focused primarily on so-called sterilized intervention, which neutralizes the effects of official currency purchases on the monetary base and thereby the interest rate. ${ }^{3}$ Unsterilized intervention, which allows foreign exchange intervention to change the monetary base, is excluded from the discussion because it clearly affects the exchange rate as any other form of monetary policy. Japan's foreign exchange intervention is assumed to be completely and instantaneously sterilized, as is generally the case for the central banks that issue the major international currencies (Federal Reserve, European Central Bank, Bank of Japan). Takagi (1991) gives empirical evidence for the pre-1991 period. We will return to this assumption in Section 6.

Since the so-called Jurgensen report (Jurgensen 1983) there has been a broad discussion as to whether sterilized foreign exchange intervention is capable of successfully targeting a certain level of the exchange rate. Sarno and Taylor (2001) give a comprehensive overview. The portfolio balance models — based on the assumption that foreign and domestic assets are imperfect substitutes — argued that sterilized intervention can effect the exchange rate by changing the relative supplies and thereby the relative returns of foreign and domestic assets (Rogoff 1984). ${ }^{4}$

An empirical test of the portfolio balance model by Dominguez and Frankel (1993) supported this view for Japanese foreign exchange intervention between 1984 and 1990. More recently Ramaswamy and Samiei (2000) argued that Japanese foreign exchange interventions in the yen/dollar market during the 1990s have been "at least partially effective" and that even sterilized interventions have mattered in the yen/dollar market. Without examining the transmission channel, an extensive study by Ito (2002) concludes that Japanese foreign exchange intervention under "Mr. Yen" Eisuke Sakakibara have produced the intended effects on the yen/dollar rate during the 1990s. Fatum and Hutchison (2003) find evidence for successful sterilized foreign exchange intervention of Japanese monetary authorities based on an event study approach. Based on a broad variety of GARCH estimations Beine and Szafarz (2003) find Japanese foreign exchange intervention successful—in particular if coordinated with the US.

3 Every buying or selling of foreign exchange by the monetary authorities alters the monetary base. If, for instance, the Japanese central bank buys foreign exchange from financial institutions as an agent of the Ministry of Finance, the official foreign reserves increase. The central bank transfers the value of the foreign currency purchase to the current deposits of the financial institutions at the central bank. Since the current deposits of financial institutions are a part of the monetary base, the monetary base will increase and money market interest rates will fall.

4 Further the so-called signalling effect is identified as an effective transmission channel of sterilized foreign exchange intervention. But as successful signalling announces a change in fundamentals (interest rate) it can be regarded as (a first step of) unsterilized intervention. 
In contrast, Sarno and Taylor (2001) argue that-at least among the currencies of the major industrial countries where capital markets have become increasingly integrated and the degree of substitutability between financial assets has increased—sterilized intervention does not affect exchange rates through the portfolio channel. According to Dominguez (1998) sterilized foreign exchange intervention is by definition unsuccessful, as it leaves the domestic money supply unchanged. If the official foreign currency transactions do not affect domestic interest rates — and thus do not trigger adjustments in the international investment portfolios—-the intervention volumes are too small in relation to the huge international foreign exchange markets to have a sustained effect.

The impact of foreign exchange intervention on volatility in foreign exchange markets is the second main line of discussion. Assuming rational expectations Dominguez (1998) suggests that fully credible and unambiguous sterilized foreign exchange intervention can reduce volatility in efficient foreign exchange markets. De Grauwe and Grimaldi (2003) show in a stochastic model with chartists and fundamentalists that systematic sterilized intervention can be effective by reducing noise generated by chartist forecast rules. Jeanne and Rose (2002) assume endogenous noise trading and argue that it is possible to reduce exchange rate volatility without sacrificing monetary autonomy.

In contrast, Schwartz (1996) contends that foreign exchange intervention is an "exe rcise in futility" which is likely to increase uncertainty and volatility. Bonser-Neal and Tanner (1996) support Schwartz's analysis using implied volatilities of currency option prices. They find that Japanese foreign exchange intervention increased the volatility in the yen/dollar foreign exchange markets during the period from 1987 to 1991. Galati and Melick (1999) contend for the period from 1993 to 1996 that Japanese foreign exchange intervention has increased foreign exchange traders' uncertainty regarding future exchange rate movements. Watanabe and Harada (2001) apply a component GARCH model to Japan's foreign exchange intervention between 1990 to 2000 and find a significant effect on lower short-term but not on long-term yen/dollar volatility.

All in all, although Sarno and Taylor (2001: 862) argue that the recent literature gives more evidence in favor of effectiveness - the general theoretical and empirical evidence for the effects of foreign exchange intervention on the level and volatility of the yen/dollar exchange rate remains mixed. For the case of Japan, however, recently the evidence in favor of effective foreign exchange intervention has become stronger (Ito 2002 and Fatum and Hutchison 2003).

\section{DATA}


To test for the impact of foreign exchange intervention on the level and volatility of the yen/dollar exchange rate we use daily data provided by Bloomberg, Datastream, the Japanese Ministry of Finance, and the Federal Reserve Board. The observation period is from April 1, 1991-when the first data on Japanese foreign exchange intervention became available — up to December 31, 2003. This corresponds to a sample size of 3326 observations.

The data on the yen/dollar exchange rate are spot prices by Bloomberg from three time zones: Tokyo closing rates (5 p.m.), New York noon (corresponding to Tokyo 2 a.m. on the next day and London 5 p.m. on the same day) and New York closing rates (Tokyo 7 a.m the next day, London 10 p.m. the same day). We analyse the $\log$ returns of the exchange rate series. The statistical properties of the first log differences time series are reported in Table 1 in comparison to the German mark/dollar exchange rate. The respective daily returns and volatilities (defined as squared returns) are plotted in Figure 3. In Table 1 the negative mean and skewness represent the prevailing yen appreciation pressure against the dollar. The kurtosis is significantly above 3 indicating leptokurtosis in both exchange rate return series, with a substantially higher value for the yen/dollar series.

Daily data on Japanese foreign exchange intervention are provided by the Japanese Ministry of Finance starting in April 1, 1991. The amounts are in billion yen subdivided into purchases and sales of dollar, mark (euro) and other (negligible) currencies. Since we focus on the yen/dollar exchange rate, only dollar transactions are included in our sample. To improve readability, the yen amounts are converted into trillion dollars based on daily exchange rates. On 3326 trading days the Ministry of Finance reports 297 dollar intervention days-264 dollars purchases and 33 dollar sales (Table 2).

The US foreign exchange intervention data are provided by the Federal Reserve Board and are subdivided into yen, mark ${ }^{5}$ and other currencies purchased and sold. The reported scale is in million dollars, we convert it into trillion dollars. 'Like for Japan only the yen transactions are included in the sample. The Federal Reserve Board reports 22 intervention days in the yen/dollar market for the observation period -18 days with dollar purchases (yen sales) and 4 days with dollar sales (yen purchases).

To control for disturbances in other asset markets, as proposed by Bonser-Neal and Tanner (1996), we use daily notations of Japanese and US stock indices-the Nikkei 300 for Japan and the Dow Jones Industrial Average for the US as provided by Datastream. The augmented Dickey and Fuller (1979) test as well as the Philips and Perron (1988) test reject the unit root hypothesis for the daily changes of the yen/dollar rate, the Nikkei 300, the DOW Jones Industrial Average as well as for (absolute) intervention data at all common confidence levels.

\footnotetext{
5 The US interventions that have taken place since the introduction of the euro are negligible.
} 


\section{REACTION FUNCTION}

Foreign exchange intervention might target the level or the volatility of the exchange rate or both. If the exchange rate appreciates (depreciates) above (below) a certain level the monetary authorities might intervene to smooth the long-term swings of the exchange rate level. For instance, the Louvre-target zones (established in February 1987) were intended to prevent the exchange rate from surpassing certain levels between dollar, yen and German mark. ${ }^{6}$ Similarly, McKinnon and Ohno (2001) as well as recent financial press reports ${ }^{7}$ suggest that during the 1990s and particularly in the new millennium Japanese monetary authorities tried to prevent the yen from rising in order to sustain the competitiveness of the Japanese export industry. As shown by Figure 4 Japanese foreign exchange intervention seems to be clustered in periods of appreciation. In some cases the financial press even believed to have identified informal target zones—for instance between 115 and 122 yen per dollar in the first seven months of $2003 .^{8}$

\section{[Figure 4 about here]}

Further, foreign exchange intervention might intend to reduce exchange rate volatility. In countries with free trade and capital flows (such as Japan and the US) exchange rate volatility is high and pervasive. If-as observed in many countries with hard or soft peg exchange rate arrangements—-monetary authorities want to reduce this exchange rate volatility, volatility triggers intervention. McKinnon and Schnabl (2003) show that such strategies are observed in many smaller East Asian countries such as Taiwan, Korea or Singapore. Successful intervention on a daily basis is translated into lower exchange rate volatility. On a less regular basis, intervention might occur in periods of turbulent foreign exchange markets. Such an influence of exchange rate volatility on intervention is less evident in Figure 5 which plots yen/dollar exchange rate volatility ${ }^{9}$ and the absolute volume of Japan's official dollar transactions.

6 The communiqué stated that current exchange rates were "broadly consistent with underlying fundamentals" (Funabashi 1988) which implied target zones around the (by that time) present levels.

7 For instance Financial Times October 17, 2003, Bloomberg News January 7 2004, Financial Times January 232004.

8 As reported by Deutsche Bank Global Investment Committee (June 16 2003) and Financial Times (August 72003 ).

9 Defined as quared returns. 
To test for the impact of both the exchange rate level and exchange rate volatility on Japanese foreign exchange rate intervention we estimate a reaction function. Most recent estimations of Japanese foreign exchange intervention reaction functions such as by Ito (2002) and by Frankel, Pierdzioch and Stadtmann (2002) have used qualitative dependent variable models which included short-term and mediumterm exchange rate fluctuations as explanatory variables.

Following this approach we use the following specification: First, the Japanese monetary authorities might decide to buy or sell dollars based on the exchange rate movements of the previous day. To capture this "leaning against the wind" we introduce the yen/dollar returns of the previous day $\left(\mathrm{r}_{\mathrm{t}-1}\right)$ as explanatory variable. Second, the decision to intervene in foreign exchange markets might be based on medium-term factors. The more the exchange rate level departs from a certain level-which is regarded as adequate exchange rate level by the monetary authorities - the higher is the probability of intervention. Ito (2002: 25) specifies the level which Japanese monetary authorities regard as appropriate during the 1990s to 125 yen per dollar. We use the mean of the yen/dollar level over the observation period for the calculation of the medium-term deviation of the yen/dollar exchange rate $\left(\left(\bar{r}-r_{t-1}\right)\right) .{ }^{\mathbf{1 0}}$

As the monetary authorities might attempt to reduce exchange rate volatility, we introduce the squared returns of the previous day as explanatory variable $\left(r_{t-1}\right)^{2}$. Furthermore, following Ito (2002) and Frankel, Pierdzioch and Stadtmann (2002) we introduce the foreign exchange intervention dummy of the previous period as explanatory variable $\left(I_{t-1}^{D}\right)$ as intervention of the current day have proven to be closely correlated with intervention of the previous day. This leads to the following specific ation:

$$
I_{t}^{D}=\alpha_{0}+\alpha_{1} r_{t-1}+\alpha_{2}\left(\bar{r}-r_{t-1}\right)+\alpha_{3}\left(r_{t-1}\right)^{2}+\alpha_{4} I_{t-1}^{D}+\varepsilon
$$

In equation (1) $I_{t}^{D}$ denotes the dummy for Japanese foreign exchange intervention of the same day. The binary probit model is estimated based on New York closing rates for purely Japanese intervention and pooled Japanese

10 Alternative benchmarks such as Ito's (2002) 125 yen/dollar bliss point, moving averages or the consumer price based purchasing power parity lead to similar results. 
and US intervention. ${ }^{11}$ The estimation results are reported in Table 3. They give very clear evidence that Japanese foreign exchange intervention targets the exchange rate level. Both variables capturing the short-term $\left(\mathrm{r}_{\mathrm{t}-1}\right)$ and medium term changes $\left(\bar{r}-r_{t-1}\right)$ in the exchange rate level have the expected negative sign and are significant at the $1 \%$-level. In contrast, there is no evidence that the volatility of the yen/dollar exchange rate $\left(r_{t-1}\right)^{2}$ had any impact on the intervention of Japanese monetary authorities during the observation period. As expected, the lagged intervention dummy $\left(I_{t-1}^{D}\right)$ is positive and significant at the $1 \%$-level.

The findings of the reaction function are crucial for the following GARCH estimations. As the level of the yen/dollar exchange rate is strongly correlated with foreign exchange intervention, the mean equation in our following GARCH estimation might be subject to endogeneity bias. In contrast as volatility does not affect foreign exchange intervention, there is no concern of endogeneity bias in the GARCH volatility equation.

\section{GARCH ESTIMATION}

To measure the effects of foreign exchange intervention on the yen/dollar rate we use a GARCH model with exogenous intervention data in both the conditional mean and variance equations as proposed by Engle (1982), Bollerslev (1986), and Baillie/Bollerslev (2002).

\subsection{Specification}

Table 2 which summarizes the stylized facts of Japanese and US foreign exchange intervention gives the necessary information for the GARCH model specification. First, we observe that in contrast to the US, Japanese foreign exchange intervention is highly focused on the yen/dollar market. Since $97.96 \%$ of Japanese foreign exchange intervention is against the US dollar ${ }^{12}$, we exclude other yen exchange rates - for instance against the euro (German mark before 1999)—from the investigation.

Second, Japan has a much higher propensity to intervene in foreign exchange markets than the US both in terms of intervention days and absolute intervention volume. The number of intervention days in the yen/dollar market is more than tenfold (Japan 297, US 22) and the discrepancy between the transactions volumes is even more pronounced (477.72 billion dollars in Japan and 8.4 billion dollars in the US). We further observe that all 22 US intervention days in the yen/dollar markets coincide with Japanese intervention days. During the observation period, the probability of US intervention conditional on Japanese intervention is $100 \%$, this implies

11 We use New York closing rates to avoid the endogeneity bias which is caused if intervention precedes exchange rate fixing.

$1248.7 \%$ of US foreign exchange intervention is against the yen during the observation period. 
that US intervention is triggered by Japanese intervention. Ito (2002) and Sakakibara (2000) provide anecdotal evidence for this. Thus, we are faced with multicollinearity.

To deal with both the asymmetric scope of intervention and multicollinearity, we use two approaches. First, we estimate the impact of Japanese intervention alone. Second, we add US and Japanese foreign exchange intervention to create one exogenous variable I which represents Japan's efforts to redirect the yen/dollar rate. This specification is justified by the fact that US intervention is only in support of Japanese intervention. We expect that both results are similar as US intervention is negligible.

Furthermore, Sarno and Taylor (2002: 846) argue that coordinated sterilized intervention between two or more countries might convince speculators that the signalled policy is more credible as opposed to a singlecountry intervention. Yet a dummy for coordinated intervention remains insignificant for the US-Japanese case since 1991. Such a dummy is therefore not included into the specification.

Third, dollar purchases in Japan clearly dominate intervention activities (Figure 1). Out of 304 intervention days dollars were purchased on 297 intervention days $(88.89 \%)$, on 33 days $(11.11 \%)$ dollars were sold. In terms of absolute intervention volumes (in dollars) 440.02 billion dollars were purchased (92.10\%) and 37.70 billion dollars were sold (7.90\%). Due to the comparatively small amount of Japanese dollar sales we do not estimate the effects of dollar purchases and dollar sales separately, but treat intervention as one time series with positive (dollar purchases) and negative signs (dollar sales). (

This leads to the following GARCH specification:

$r_{t}=b_{0}+b_{1} I_{t}+b_{2} N i k k e j+b_{3} D O W_{t}+\varepsilon_{t}$,

$\left.\varepsilon_{t}\right|_{\Omega_{t-1}} \sim N\left(0, h_{t}\right)$,

$h_{t}=\omega+\sum_{i=1}^{q} \alpha_{i} \varepsilon_{t-i}^{2}+\sum_{i=1}^{p} \beta_{i} h_{t-j}+\gamma_{1}\left|I_{t}\right|+\gamma_{2} N i k k e i_{t}^{2}+\gamma_{3} D O W_{t}^{2}$.

In equation (2) $r_{t}$ denotes the logarithmic returns of the yen/dollar spot exchange rate (conditional mean) as plotted in the upper left panel of Figure 3. As proposed by Bonser-Neal and Tanner (1996), we include the daily returns of Japanese and US stock markets—Nikkei 300 and DOW Jones Industrial—as exogenous variables to control for the impact of disturbances in other asset markets. The correlation between the Nikkei and DOW series does not affect our main findings. Excluding one or the other variable does not change the results. We do not 
include any dummies for the announcement of interest rate changes, since estimations with such dummies did not yield any significant results. ${ }^{13}$ In contrast to Dominguez (1998) and Baillie and Osterberg (1997) we do not include dummy variables for the day of the week and holidays in the variance equation. Doornik and Ooms (2000) show that this procedure leads to degenerated likelihood surfaces .

In equation (3) the disturbances $\varepsilon_{t}$ are modelled as normally distributed conditional on the information set $\Omega_{\mathrm{t}-1}$ available at time t-1, with zero mean and variance $\mathrm{h}_{\mathrm{t}}$. Equation (4) models the volatility of the yen/dollar exchange rate as plotted in the lower left panel of Figure 3. The variance $h_{t}$ depends on past disturbances $\mathrm{e}_{\mathrm{t}-\mathrm{i}}$, the lagged conditional variance $\mathrm{h}_{\mathrm{t}-\mathrm{j}}$, the absolute official foreign currency intervention $\left|\mathrm{I}_{\mathrm{t}}\right|,{ }^{14}$ and the volatility in the Japanese and US share markets defined as the squares of daily returns-Nikkei $i_{\mathrm{t}}^{2}$ and $D o w_{\mathrm{t}}^{2}$.

To capture the immediate impact of foreign exchange intervention on exchange rate volatility, the intervention variable $\left|\mathrm{I}_{\mathrm{t}}\right|$ and the control variables $N i k k e i_{\mathrm{t}}{ }^{2}$ and $D o w_{\mathrm{t}}{ }^{2}$ are not lagged in the volatility equation. This specification does not suffer fromsimultaneity bias, as for equation (1) the impact of volatility on intervention remained insignificant.

The lag-structure of our GARCH model is specified in two ways. First we specify the number of lags by the Bayes information criterion (BIC) for models of the order $p \in\{1, \ldots, 7\}$ and $q \in\{1, \ldots, 7\}$. As a benchmark, we also estimate the $\operatorname{GARCH}(1,1)$ specification, which is usually sufficient to eliminate ARCH-effects from the residuals .

\subsection{Global Results}

Table 4 reports the estimates of equations (1) to (3) on daily data between April 1, 1991, and December 31, 2003. The results are reported for the yen/dollar exchange rate in different markets and thereby time zones, i.e. Tokyo 5 p.m. (closing rates), New York noon (which is equivalent to London 5 p.m.) and New York 5 p.m. (closing rates). The results are reported for Japanese intervention only and for pooled Japanese and US intervention. US interventions alone are not reported, because they would be subject to omitted variable bias. ${ }^{15}$ Furthermore, we report the lag order specification favored by a search for the lowest BIC as well as a GARCH(1,1) specification.

13 As shown by Watanabe (1994), Japanese foreign exchange intervention might signal a change in fundamentals (monetary policy) - at least before 1999 when nominal interest rates reached the zero bound. The failure to trace the impact of the announced interest rate changes on the exchange rate might be due to the fact that markets gradually anticipate interest rate changes.

14 We assume that dollar sales and dollar purchases affect the volatility in the same way.

15 The omitted variable is Japanese intervention which coincides with US intervention and has a much larger scope. 
Japanese intervention which takes place during the Tokyo market opening hours precedes all the three exchange rates. Pooled intervention only clearly precedes the New York closing rate. This might be also the case if the New York Fed were to intervene on behalf of the Japanese monetary authorities in the US markets.

In Table 4 we observe that the global estimation results are very similar for both specifications and all time zones (as exchange rates between the time zones will be closely correlated). The intervention coefficient $b_{1}$ is positive and highly significant for most specifications, suggesting evidence for successful intervention on the same day. We treat this result with caution, as autocorrelation between the endogenous and exogenous variable might persist and endogeneity might distort the results.

Instead, following Dominguez (1998) we regard foreign exchange intervention as successful, if intervention significantly reduces the volatility of the yen/dollar exchange rate. As argued by Schwartz (1996), unsuccessful foreign exchange intervention is likely to increase exchange rate volatility.

In equation (4), the coefficient $\gamma_{1}$ estimates the impact of the absolute foreign exchange intervention on the volatility of the yen/dollar exchange rate. The results, which are shown in Table 4, are contradictory. Although some $\gamma_{1}$-coefficients are highly significant they exhibit different signs for different time zones and GARCH specifications. Japanese foreign exchange intervention is associated with higher or lower volatility in foreign exchange markets at highly significant levels. To this end, the global GARCH estimation does not yield any clear results on the effectiveness of Japanese foreign exchange intervention.

\section{[Table 4 about here]}

Hillebrand (2004) shows that neglecting parameter changes in GARCH models leads to an estimated sum of autoregressive parameters close to one. When we estimate simple GARCH(1,1) models without explanatory variables in the conditional variance equation, the sum of the estimated autoregressive parameters is close to one for all specifications considered here. When the intervention series are introduced as explanatory variables, this sum is reduced substantially, mostly to the order of 0.90 . This gives some indication that the intervention series capture changing volatility regimes. Segmenting the data and estimating the model locally will shed more light on this issue.

\subsection{Local Results}

The global estimation might not account for parameter changes that are frequently observed for the volatility of financial time series (for example, Andreou and Ghysels 2002). To cope with this problem we re-estimate our 
GARCH model for sub-periods. ${ }^{16}$ In a first step, we subdivide our observation period into calendar years. Although this partition is arbitrary from a statistical perspective and might yield too short observation periods we get a first notion of changing parameters. We use New York closing rates for this estimation to ensure that intervention clearly precedes the exchange rate fixing. The results of the local yearly GARCH estimations are reported in Table 5. The $\mathrm{b}_{1}$ coefficients yield significant coefficients in the years 1991, 1995, 1997, and 1998 to 2003 for the BIC specification. For all these years except 1991 the coefficient is positive-possibly indicating successful intervention. For the $\operatorname{GARCH}(1,1)$ specification the results are similar, but in both cases the endogeneity bias might be substantial.

In contrast to the $b_{1}$ coefficients the ? coefficient in the volatility equation is not subject to possible endogeneity bias. The $?_{1}$ coefficient is positive and significant in the years 1993, 1995, and 1997 suggesting that Japanese foreign exchange intervention increased the volatility of the yen/dollar exchange rate. In the year 1996 and from 1999 up to 2003 the ? $?_{1}$ coefficient is negative and significant at the common levels providing possibly evidence of successful Japanese foreign exchange intervention.

Understanding that data segmentation considerably affects our estimation results we test for the robustness of our results to different observation periods. Beine and Szafarz (2003: 6) suggest that Japanese foreign exchange intervention exhibits clear patterns of clusters. Based on Figure 1 we build nine periods of intervention clusters, which are indicated in the first line of Table 6. Then we set the boundaries of the segments mid-way between the last and the first day of each intervention period. Although these intervention clusters are again statistically arbitrary we obtain additional evidence on the effect of data segmentation on our estimation results.

The main findings as reported in Table 6 widely match the findings of the yearly estimations. In the first cluster (1991) the $?_{1}$ coefficient is insignificant at the common levels. In the second cluster (1992) there is some evidence in favour of successful intervention as the ? coefficient is negative and highly significant. Between 1993 and 1998 (clusters 3 to 5) Japanese foreign exchange intervention seems to have been ineffective as it seems to have increased exchange rate volatility (positive and highly significant $?_{1}$ coefficients). In the sixth cluster (1997/98) the $?_{1}$ coefficient is positive, but insignificant. For the period from 1999 up to 2003 (clusters 7 to 9), there is evidence in favor of successful intervention. The $?_{1}$ coefficients are highly significant for all three sub-periods.

\footnotetext{
16 The estimations of the reaction functions as specified in equation (1) for the respective sub-periods lead to the same result as the global reaction function.
} 
Based on the findings reported in Table 5 and Table 6 we can roughly divide the data into two regimes: From 1991 up to the late 1990s, Japanese foreign exchange intervention has increased exchange rate volatility. Starting from the late $1990 \mathrm{~s}$, it has reduced volatility.

\section{CHANGE POINT DETECTION}

Although the sub-divided GARCH estimations give a more precise view of changing parameter regimes in comparison to the global model, a non-arbitrary segmentation is desirable. We use a change point detector for ARCH models as proposed by Kokoszka and Leipus (1999) to identify sub-periods. The detector can be applied to a standard GARCH(1,1) model with constant mean return:

$r_{t}=\mu+\varepsilon_{t}$

$\left.\varepsilon_{t}\right|_{\Omega_{t-1}} \sim N\left(0, h_{t}\right)$

$h_{t}=\omega+\alpha \varepsilon_{t-1}^{2}+\beta h_{t-1}$.

In equation (8), $r_{\mathrm{t}}$ are the daily returns of the yen/dollar exchange rate, $\mu$ is the constant mean. The disturbances $\varepsilon_{\mathrm{t}}$ are assumed to be normally dis tributed conditional on the information $\mathrm{O}_{\mathrm{t}-1}$ available at the time $\mathrm{t}-1$ (9). The mean of the disturbances is assumed to be zero and the variance $h_{t}$ depends on the square of the lagged disturbance of the previous period $\varepsilon_{\mathrm{t}-1}$ and the conditional variance of the previous period $\mathrm{h}_{\mathrm{t}-1}(10)$.

Consider a time series generated by (8) and (9) with a single change point in equation (10) at point $\mathrm{k}^{*}$ where the data generating parameter vector changes from $\theta_{1}=\left(\mu, \omega_{1}, \alpha_{1}, \beta_{1}\right)$ to $\theta_{2}=\left(\mu, \omega_{2}, \alpha_{2}, \beta_{2}\right)$. The change-point detector is the estimator $\hat{k}$ of $\mathrm{k}^{*}$ defined by

$\hat{k}=\min \left\{k:\left|R_{k}\right|=\max _{1 \leq j \leq n}\left|R_{j}\right|\right\}$

where $\mathrm{k}$ and $\mathrm{j}$ are indices for time, and the statistic $\mathrm{R}_{\mathrm{k}}$ is given by

$$
R_{k}=\frac{k(n-k)}{n^{2}}\left(\frac{1}{k} \sum_{j=1}^{k} r_{j}^{2}-\frac{1}{n-k} \sum_{j=k+1}^{n} r_{j}^{2}\right)
$$


Intuitively, the detector measures the distance $R_{k}$ between the means of the two segments that are induced by the hypothetical change point $\mathrm{k}$. The estimated change point is set where this distance becomes maximal. For the rare case that more than one maximum exists, the first one is chosen. In the stationary GARCH(1,1) model, the volatility mean is given by $E h_{t}=E \varepsilon_{t}^{2}=\omega /(1-\alpha-\beta)$. In other words, the change-point detector identifies segments of different volatility means $E h_{t}\left(\theta_{1}\right)=\omega_{1} /\left(1-\alpha_{1}-\beta_{1}\right)$ and $E h_{t}\left(\theta_{2}\right)=\omega_{2} /\left(1-\alpha_{2}-\beta_{2}\right)$. Kokoszka and Leipus (1999) show that this estimator is consistent, converges in probability to the true change point $\mathrm{k}^{*}$ with rate $1 / \mathrm{n}$, and that the asymptotic distribution is given by

$$
\sqrt{n} R_{k} \sim \sigma W^{0}(t)
$$

where $\mathrm{W}^{0}(\mathrm{t})$ is a Brownian Bridge and $\sigma^{2}$ is the variance of $R_{k}$. We follow Andreou and Ghysels (2002) and use the VARHAC estimator of Den Haan and Levin (1997) for $\sigma$. Applying the detector to the New York closing rate, we identify three change-points which are significant at the 5\% level. These are 05/07/1997, 04/03/2000, and 09/20/2002 as indicated in Table 7.

We use these new segments for local GARCH estimations. The results as plotted in Table 8 show a clear trend over time: While interventions correlate positively and significantly with volatility in the first segment from 1991 through 1997, the effect is ambiguous in the second segment between 1997 and 2000. The GARCH $(1,4)$ specification favored by the BIC shows a significantly negative correlation between interventions and volatility, the coefficient in the $\operatorname{GARCH}(1,1)$ specification remains insignificant. In the third segment from 2000 through 2002, as well as in the fourth segment from 2002 through 2003, the BIC favors the GARCH(1,1) specification. In these segments, the correlation between volatility and intervention is significantly negative.

Together with the results of the estimation of the reaction function in Section 4, it seems that between 1991 and 1997, interventions of the Japanese authorities in the yen/dollar market increased the volatility of the exchange rate and therefore were unsuccessful. After a transitional period from 1997 to 2000, where the effect is not clear-cut, interventions seem successful in reducing exchange rate volatility

The conclusion that there is a structural break with respect to the effectiveness of Japanese foreign exchange intervention poses the question about the adequate starting point for the period of effective foreign exchange intervention. The yearly estimations as reported in Table 5 would suggest effectiveness starting in January 1999. The estimation based on intervention clusters as reported in Table 6 suggest effective Japanese foreign 
exchange intervention starting from December 1999. The estimation based on change point detection suggests effective Japanese foreign exchange intervention starting in March 2000.

Although as outlined in Section 7 economic evidence might provide additional information concerning the "exact starting point" of effective Japanese foreign exchange intervention, any clear determination will be arbitrary. Nevertheless, to get an additional notion on the evolution of the effects of Japanese foreign exchange intervention we compute a rolling GARCH estimation for the volatility coefficient $?_{1}$.

For this purpose we have to make two restrictive assumptions. First, for simplicity we have to restrict the estimation to the $\operatorname{GARCH}(1,1)$ specification which might incorporate some misspecifications for single coefficients as shown above. Second, we have to select a window size. To minimize possible bias caused by the window size rolling GARCH coefficients are computed for the windows of 500, 750, 1000, 1250 and 1500 trading days. All window sizes yield by and large the same results. For the sake of brevity we report the results for the 500 and 1500 trading days.

Figure 6 shows the t-statistics for the rolling $\mathrm{GARCH}(1,1)-?_{1}$-coefficients. During the first sub-period, it shows a tendency for positive and significant t-values. Japanese foreign exchange intervention seems to increase the volatility of the yen/dollar exchange rate at statistically significant levels. After a certain transition period the result is reversed. The $?_{1}$-coefficients tend to be negative at statistically significant levels. At the latest in the new millennium Japanese foreign exchange intervention seems to reduce the volatility of the yen/dollar exchange rate thereby providing evidence in favor of recently successful intervention.

Increasing the window size emphasizes this. During the first part of the 1990s the coefficient seems to be positive at statistically significant levels. The levels of significance gradually decline while the coefficient turns negative in the new millennium. Japanese foreign exchange intervention seems to have turned to towards success.

\section{INTERPRETATION OF FINDINGS AND CONCLUSION}

While the global GARCH estimations on the effects of Japanese foreign exchange intervention on the volatility of the yen/dollar exchange rate were inconclusive, the local GARCH estimation provided evidence in favor of a structural break. Up to the late 1990s Japanese foreign exchange intervention seems to have increased the volatility of the yen/dollar exchange rate. In the millennium foreign exchange intervention is associated with lower exchange rate volatility. Neither arbitrary nor non-arbitrary segmentation by the change point detection allow 
determining an exact turning point. Yet, the rolling GARCH coefficients suggest that the structural break would be around the millennium.

In line with our findings, recently the financial press has claimed frequently that Japanese foreign exchange intervention has been successful. ${ }^{17}$ McKinnon and Schnabl (2003) use the euro/dollar exchange rate as a benchmark to show that since early 2001 the yen appreciated much less against the dollar than the euro. Can this ostensive success of Japanese foreign exchange intervention be explained from a theoretical perspective?

As outlined in section 2, unsterilized intervention has a higher probability of success than sterilized intervention. According to Eldred (2004) Japanese foreign exchange intervention can be interpreted as being fully and automatically sterilized because the Japanese Ministry of Finance raises the amount of yen which is required to buy dollars by issuing financing bills. To this end the theoretical evidence in favor of successful intervention would be weak.

However, Japanese foreign exchange intervention since 1999 might be regarded as unsterilized because the monetary base could grow at any desired level without interfering with the zero-interest rate target of monetary policy. Even if foreign exchange intervention was formally sterilized, a simultaneous increase of the monetary base would make it equivalent to unsterilized intervention.

Yet, after March 2001 when the Bank of Japan shifted the operating target for money market operations from the uncollateralized overnight call rate to the outstanding balance of current accounts (Bank of Japan 2001) there is a "built-in propensity" to sterilize foreign exchange intervention. If, for example, the overnight target ceiling of the current account balances is exhausted at 30 trillion yen, an injection of an additional 1 trillion yen by foreign exchange intervention must be drained from the system in order to sustain the upper limit.

Therefore, if Japanese foreign exchange intervention has been effectively sterilized since March 2001 depends on the flexibility of the target ceiling on the Bank of Japans current account balances. As shown in Figure 8 the ceiling of the Bank of Japan current accounts has grown steadily on a monthly basis ${ }^{18}$ from 4 trillion yen in March 2001 to 27-32 trillion yen by the end of the year 2003. This considerable increase in current account balances was large enough to accommodate the cumulated foreign exchange interventions of 22 trillion yen during this period. The target ceiling of the Bank of Japan current account balances seems to have closely followed (or leaded) the cumulative foreign exchange intervention.

17 Financial Times January 23 2004, The Economist February 14, 2004, 72, Financial Times, August 8, 2003. Horst Köhler, managing direction of IMF, mentioned that [Tokyo's unprecedented foreign exchange intervention] "is pragmatic and helps stabilizing the financial system" (Financial Times, February 252004 ).

18 There is no evidence that the current balances were adjusted on a daily basis. 
And the transmission channel? As pointed out by Okina and Shiratsuka (2000) in the liquity trap interest rates are clearly not a transmission channel. Therefore Spiegel (2003) argues that the decision to leave foreign exchange intervention effectively unsterilized might have affected the investor's expectations regarding the future path of the yen/dollar rate. As the Japanese monetary authorities have clearly demonstrated that Japanese foreign exchange intervention is not limited by monetary constraints, this might have encouraged investors to hold more yen assets. A shift back to sterilized intervention as observed in September 2003 (Figure 8) might offset these effects, if the Bank of Japan strives to return to full monetary independence.

\section{REFERENCES:}

Andreou, E., Ghysels, E., 2002, Detecting Multiple Breaks in Financial Market Volatility Dynamics. Journal of Applied Econometrics 17,pp. 579-600.

Baillie, R., Bollerslev, T., 2002. The Message in Daily Exchange Rates: A Conditional-Variance Tale. Journal of Business and Economic Statistics 7 (20), pp. 60-68.

Baillie, R., Osterberg, W., 1997. Why Do Central Banks Intervene? Journal of International Money and Finance 16 (6), pp. 909-919.

Beine, M., Szafarz, A., 2002. The Design of Effective Central Bank Interventions: the Yen/Dollar Case. Mimeo.

Black, F., 1976. Studies of Stock Price Volatility Changes. American Statistical Association, Proceedings of the Business and Economics Statistics Section, pp. 177-181.

Bollerslev, T., 1986. Generalized Autoregressive Conditional Heteroskedasticity. Journal of Econometrics 31, pp. 307-327.

Bollerslev, T., Wooldridge, J., 1992. Quasi-Maximum Likelihood Estimation and Inference in Dynamic Models with Time - Varying Covariances. Econometric Reviews 11 (2), pp. 143-172.

Bonser-Neal, C., Tanner, G., 1996. Central Bank Intervention and the Volatility of Foreign Exchange Rates: Evidence from the Options Market. Journal of International Money and Finance 15, pp. 853-878.

De Grauwe, P., Grimaldi, M., 2003. Intervention in the Foreign Exchange Market in Model with Noise Traders. Mimeo.

Den Haan, Levin, A., 1997. A Practitioner's Guide to Robust Covariance Matrix Estimation. In: Maddala, G., Rao, C.(eds.): Handbook of Statistics Vol. 15: Robust Inference, North-Holland: Amsterdam.

Dickey, D., Fuller, W., 1979. Distribution of Estimators for Autoregressive Time Series with a Unit Root. Journal of the American Statistical Association 74, pp. 427-431. 
Dominguez, K., 1998. Central Bank Intervention and Exchange Rate Volatility. Journal of International Money and Finance 17, pp. 161-190.

Dominguez, K., Frankel, J., 1993. Does Foreign Exchange Intervention Work? Institute for International Economics, Washington DC.

Doornik, J.A., Ooms, M. 2000. Multimodality and the GARCH Likelihood. Working paper.

http://www.feweb.vu.nl/econometriclinks/ooms/papers/

Eldred, B. 2004: Yen Issues. Mimeo.

Engle, R., 1982. Autoregressive Conditional Heteroscedasticity with Estimates of the Variance of United Kingdom Inflation. Econometrica 50 (4), pp. 987-1007.

Fatum, R., Hutchison, M., 2003. Is Sterilized Foreign Exchange Intervention Successful after All? An Event Study Approach. Economic Journal 113, pp. 390-411.

Frenkel, M., Pierdzioch, C., Stadtmann, G., 2002. Bank of Japan and Federal Reserve Interventions in the Yen/U.S. Dollar Market: Estimating the Central Bank’ Reaction Functions. Mimeo.

Frenkel, M., Pierdzioch, C., Stadtmann, G., 2003. Bank of Japan and Federal Reserve Interventions in the Yen/U.S. Dollar Market: Estimating the Central Banks’ Reactions Functions. Mimeo.

Frenkel, M., Pierdzioch, C., Stadtmann, G., 2004. The Accuracy of Press Reports Regarding the Foreign Exchange Interventions of the Bank of Japan. Journal of International Financial Markets, Institutions and Money 14 (2004) pp. 25-36.

Funabashi, Y., 1988. Managing the Dollar: from Plaza to Louvre, Washington DC.

Galati, G., Melick, W., 1999. Perceived Central Bank Intervention and Market Expectations: An Empirical Study of the Yen/Dollar Exchange Rate, 1993-96. BIS Working Paper No. 77.

Goyal, R., McKinnon, R., 2003: Japan's Negative Risk Premium in Interest Rates: The Liquidity Trap and Fall in Bank Lending. The World Economy 26(3), pp. 339-363.

Hillebrand, E., 2004. Neglecting Parameter Changes in GARCH Models. Forthcoming in the Journal of Econometrics, Annals Issue on Modeling Structural Breaks, Long Memory, and Stock Market Volatility, http://www.bus.lsu.edu/economics/faculty/ehillebrand/personal/research.htm

Ito, T., 2002. Is Foreign Exchange Intervention Effective? The Japanese Experience in the 1990s. NBER Working Paper 8914.

Jeanne, O., Rose, A., 2002. Noise Trading and Exchange Rate Regimes. Quarterly Journal of Economics 117, pp. 537-569.

Jurgensen, P., 1983. Report of the Working Group on Exchange Market Intervention. 
Kokoszka, P., Leipus, R., 1999. Testing for Parameter Changes in ARCH Models. Lithuanian Mathematical Journal 39(2), pp 182-195.

McCallum, B., 2000. Theoretical Analysis Regarding a Zero Lower Bound on Nominal Interest Rates. Journal of Money, Credit and Banking 32, 4, pp. 870-904.

McKinnon, R., Ohno, K., 1997. The Foreign Exchange Origin of Japan's Economic Slump and Low Interest Rate Liquidity Trap. World Economy 25, 3, pp. 279-315.

McKinnon, R., Schnabl, G., 2003. The East Asian Dollar Standard, Fear of Floating and Original Sin. Hong Kong Institute for Monetary Research Working Paper No. 11/2003.

Okina, K, Shiratsuka, S. 2000. The Illusion of Unsterilized Intervention. Shukan Toyo Keizai, January 152000.

Phillips, P., Perron, P., 1988: Testing for a Unit Root in Time Series Regression. Bio metrika 75, pp. 335-346.

Pilling, D., 2003. Tokyo spends record amount to weaken yen. Financial Times, August 8, 2003.

Ramaswamy, R., Samiei, H., 2000. The Yen-Dollar Rate. Have Interventions Mattered? IMF Working Paper WP/00/95.

Rogoff, K., 1984. On the Effects of Sterilized Intervention: An Analysis of Weekly Data. Journal of Monetary Economics 14, pp. 133-150.

Sakakibara, E., 2000. nihon to sekai ga furueta hi [The Day when Japan and the World Trembled], Tokyo Chuokoron-Shinsha.

Sarno, L., Taylor, M., 2001. Official Intervention in the Foreign Exchange Market: Is it Effective and, if so, How Does it Work? Journal of Economic Literature 39, pp. 839-868.

Schnabl, G., 2001. Weak Economy and Strong Currency - the Origins of the Strong Yen in the 1990s. Quarterly Journal of Economic Research 70, pp. 489-503.

Schwartz, A., 1996. U.S. Foreign Exchange Intervention since 1962. Scottish Journal of Political Economy 43, 4, pp. 379-397.

Schwartz, A., 2000. The Rise and Fall of Foreign Exchange Market Intervention. NBER Working Paper 7751.

Svensson, L., 2001. The Zero Bound in an Open Economy: A Foolproof Way of Escaping from a Liquidity Trap. Bank of Japan Monetary and Economic Studies 19, pp. 277-306.

Takagi, S., 1999. Foreign Exchange Market Intervention and Domestic Monetary Control in Japan, $1973-89$. Japan and the World Economy 3, pp. 147-180.

Watanabe, T., Harada, K. 2001. Effects of the Bank of Japan's Intervention on Yen/Dollar Exchange Rate Volatility. Mimeo. 
Watanabe, T., 1994. The Signalling Effect of Foreign Exchange Intervention: the Case of Japan. In: Glick, R., Hutchison, M. (Eds.): Exchange Rate Policy and Interdependence: Perspectives from the Pacific Basin, Cambridge, pp. 258-286. 
Figure 1: Japan - Absolute and Cumulated Daily Dollar Foreign Exchange Intervention

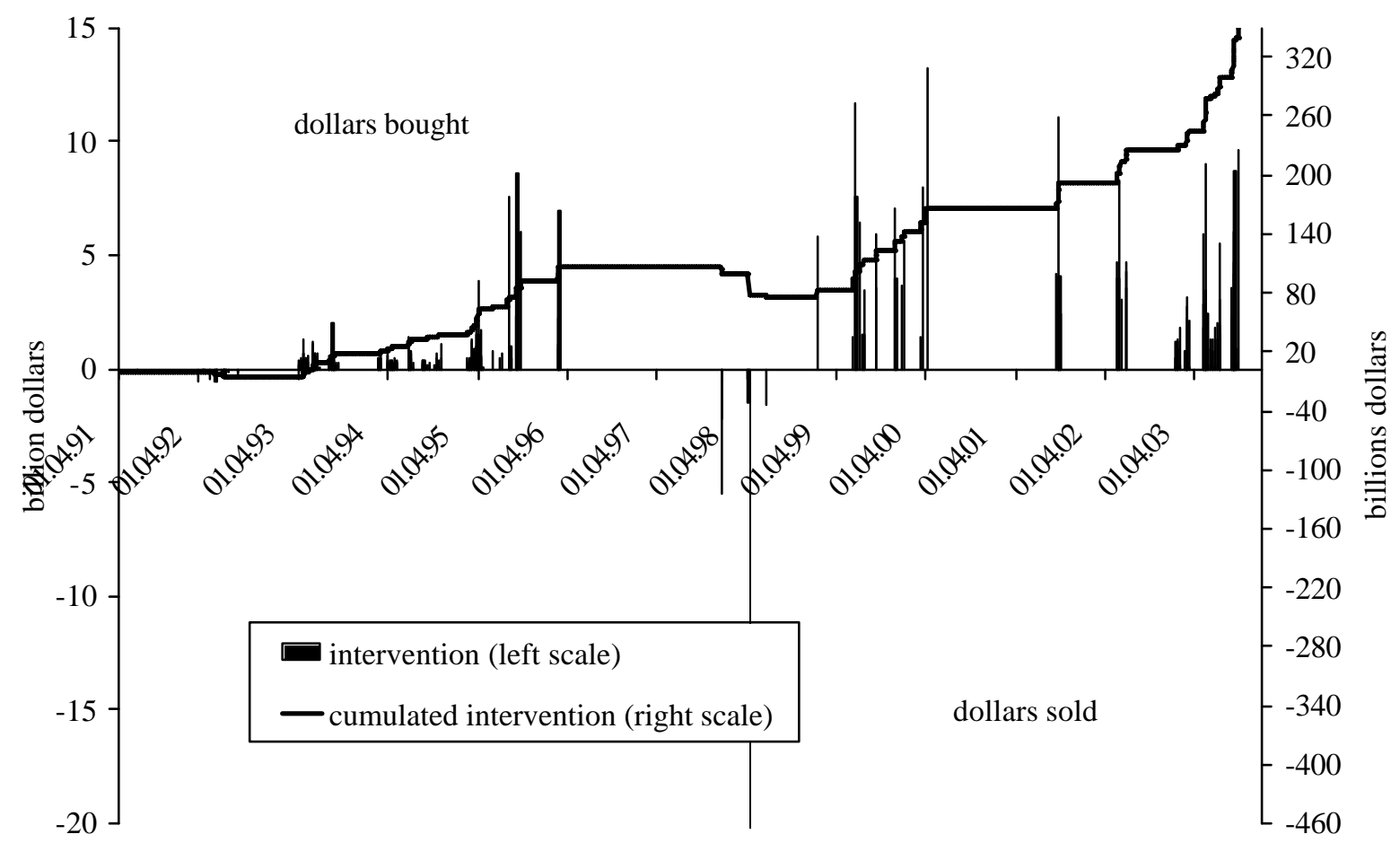

Source: Japan: Ministry of Finance. April 1991 - December 2003. Note different scales for Japan and the US (Figure 2). 
Figure 2: US - Absolute and Cumulated Daily Yen Foreign Exchange Intervention

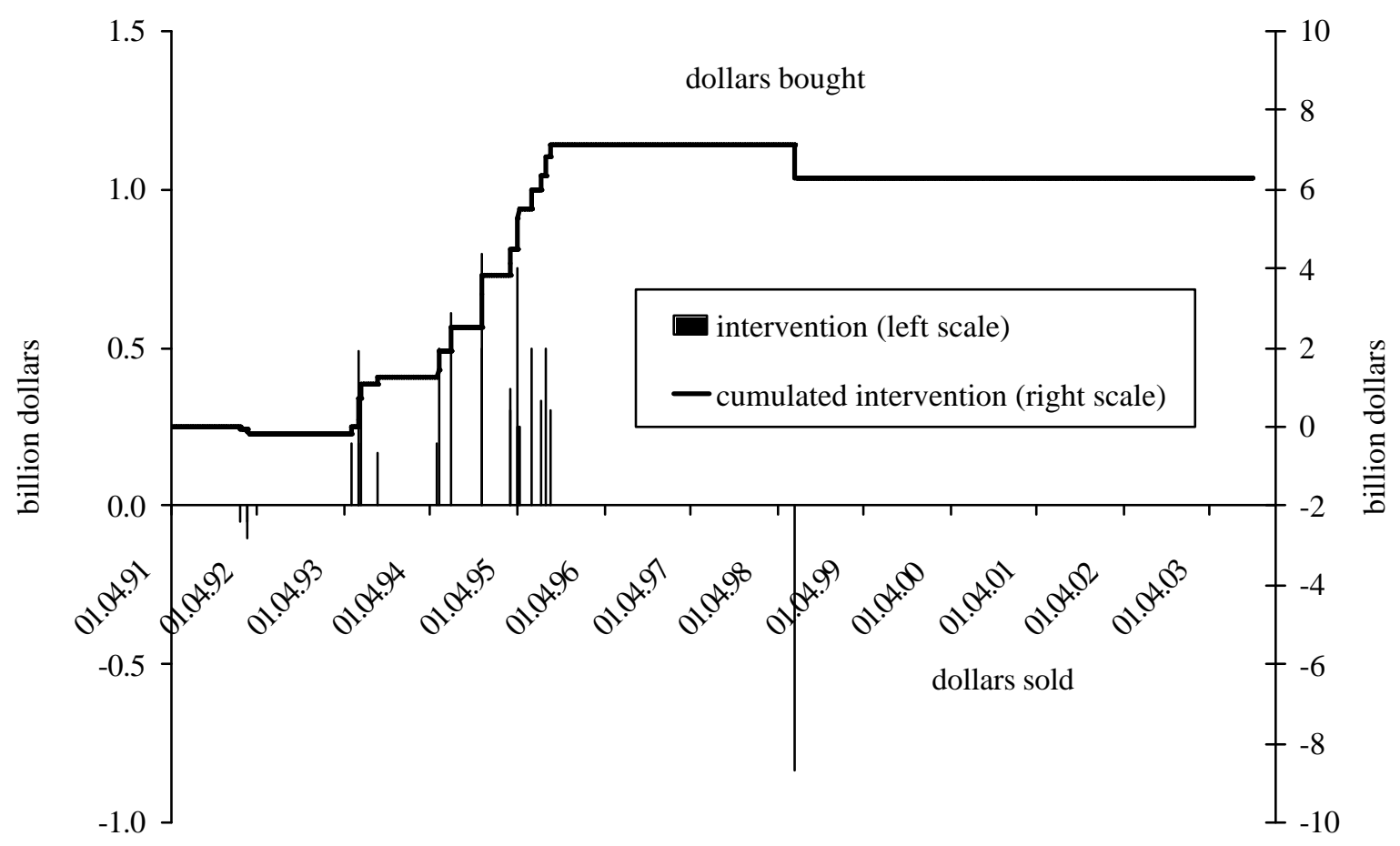

Source: US Federal Reserve Board. Billion Dollars. April 1991 - December 2003. Note different scales for US and Japan (Figure 1). 
Figure 3: Daily Yen/Dollar and German Mark/Dollar Exchange Rates (4/1/91 - 12/31/03)
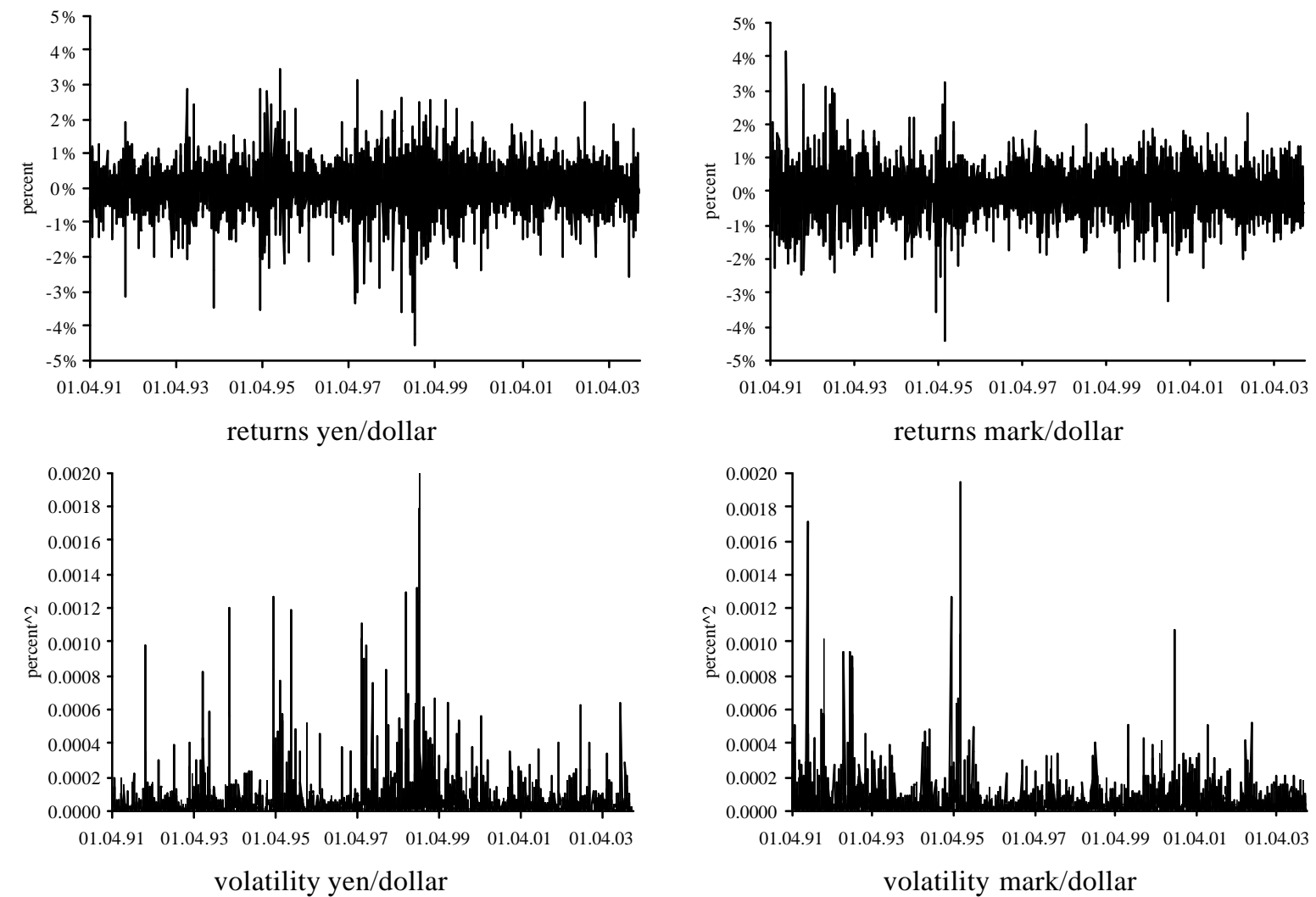

Source: Datastream. Daily volatilities defined as square of daily percentage changes. The DM represents the euro since January 1999. 
Figure 4: Foreign Exchange Intervention and Yen/Dollar Exchange Rate

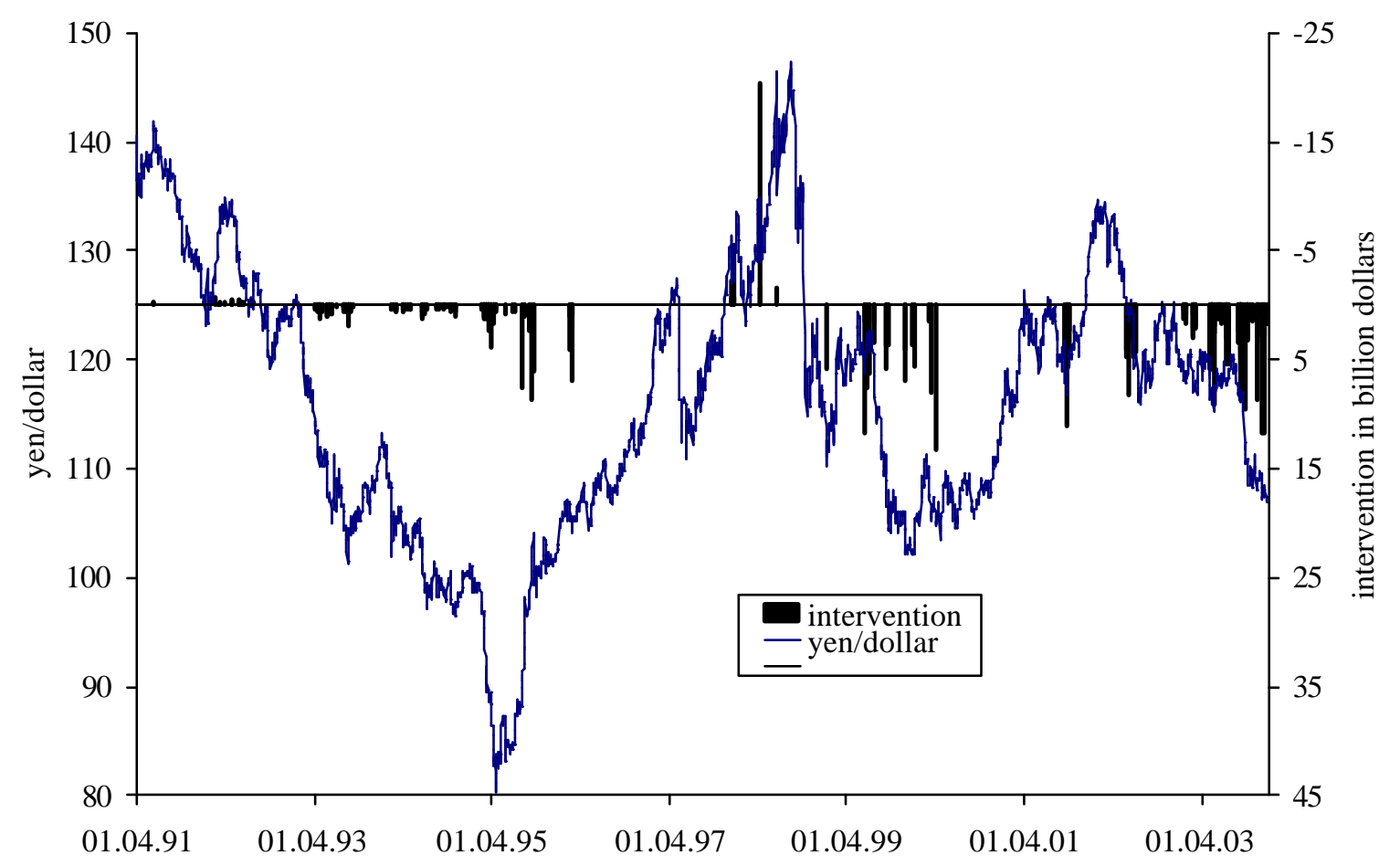

Source: Blommberg, Japan: Ministry of Finance. Foreign exchange intervention in billion dollars. April 1991 December 2003. 
Figure 5: Foreign Exchange Intervention and Yen/Dollar Exchange Rate Volatility 1991:04-2003:12

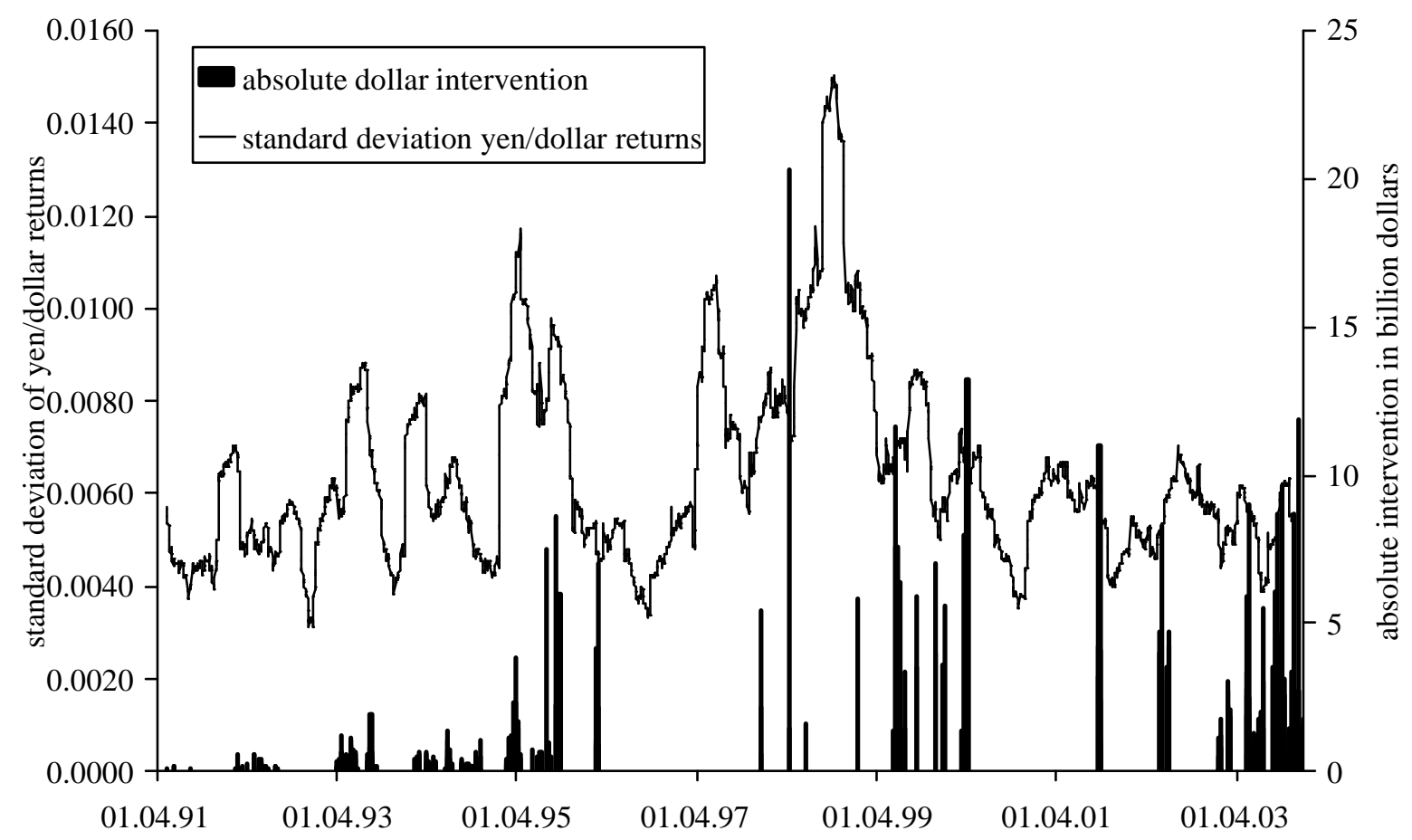

Source: Bloomberg. Foreign exchange intervention in billion dollars. April 1991 - December 2003. Volatility defined as 60 days rolling standard deviations of the daily percent yen/dollar exchange rate changes around day t. 
Figure 6: Rolling GARCH(1,1) t-Statistics for $?_{1}$ (Window = 500 Observations $)$

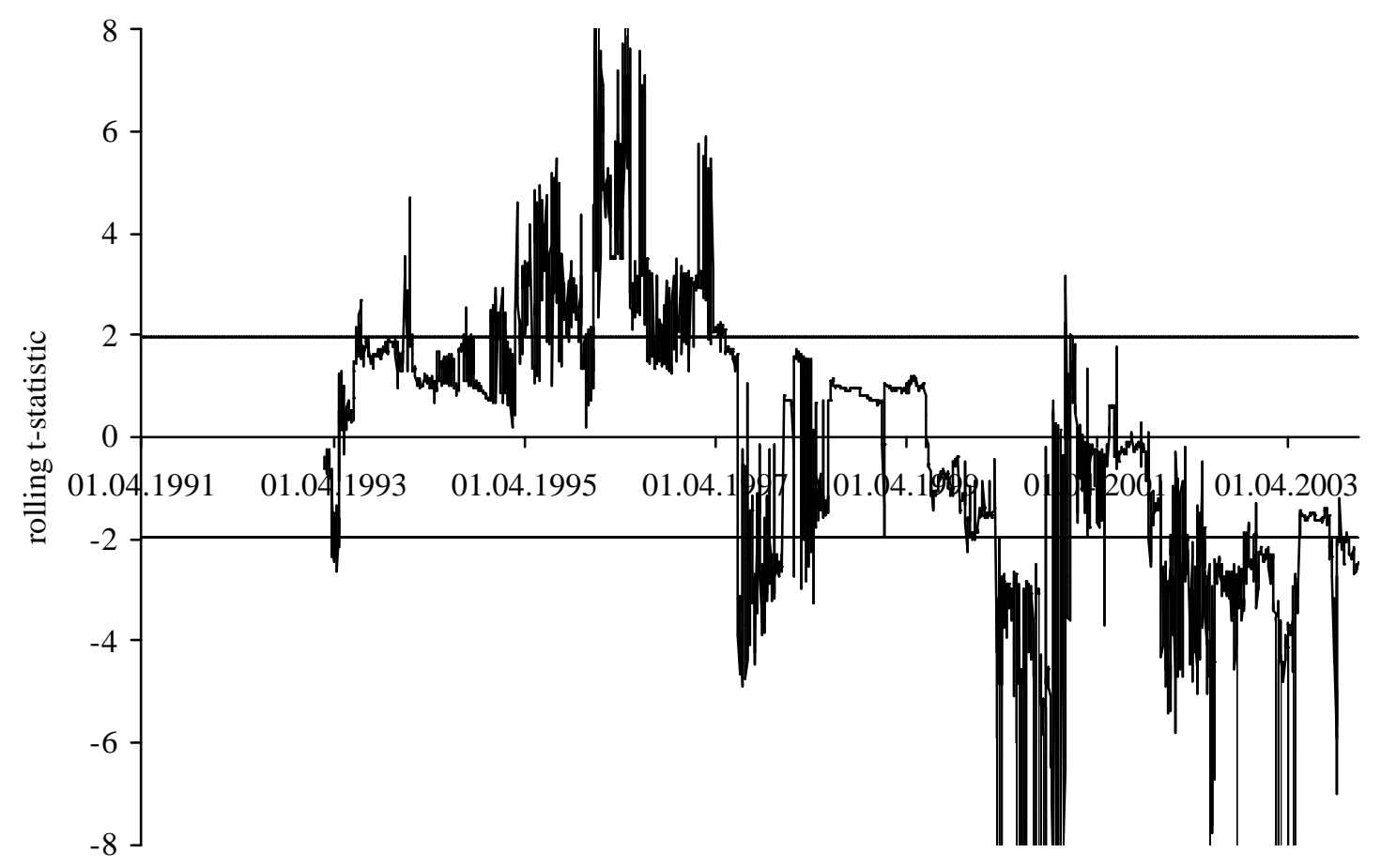

Source: Bloomberg (New York Closing Rates) 
Figure 7: Rolling GARCH(1,1) t-Statistics for $?_{1}$ (Window = 1500 Oberservations)

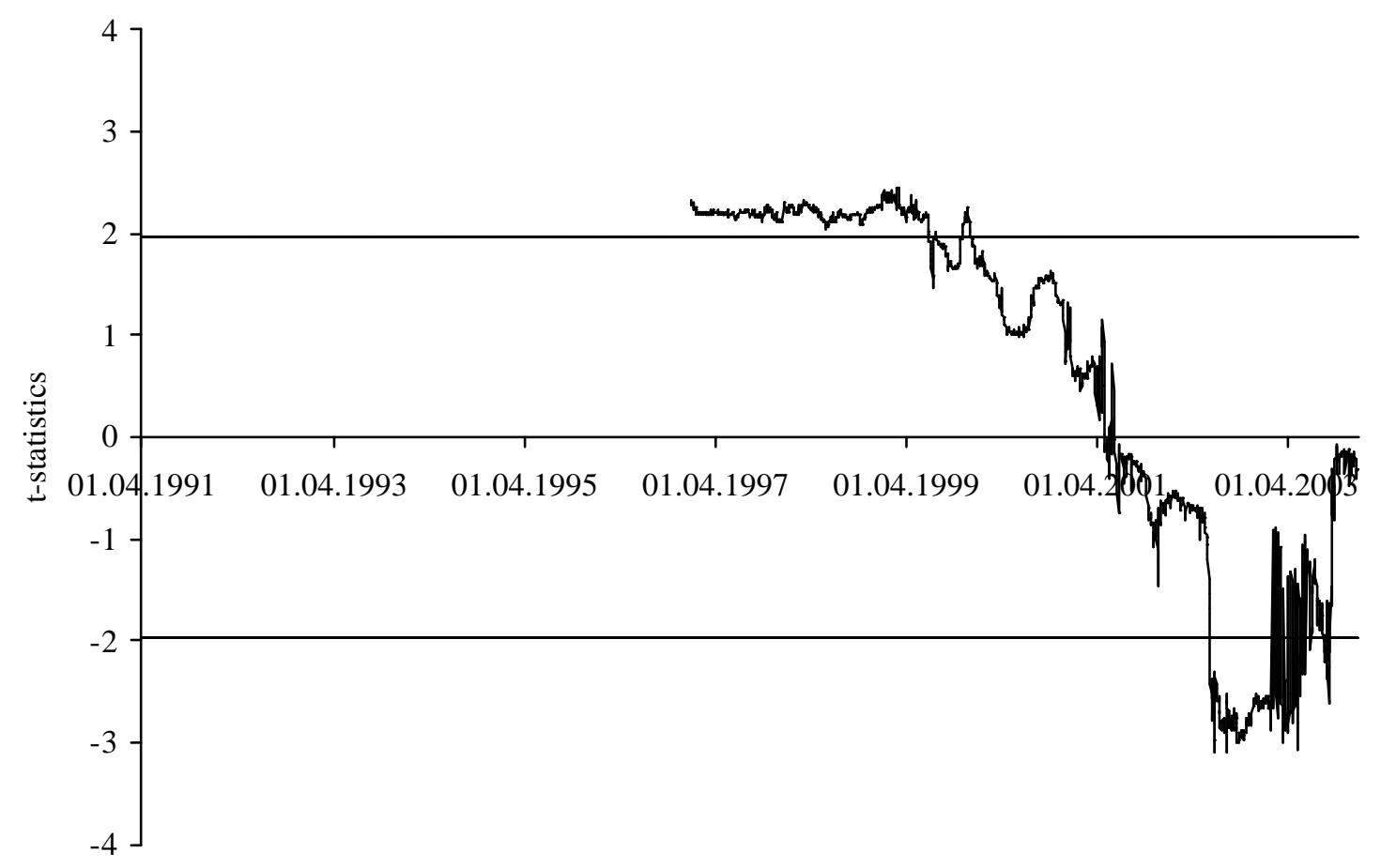

Source: Bloomberg (New York Closing Rates)

Figure 8: Bank of Japan Current Account Balance and MOF Foreign Exchange Intervention

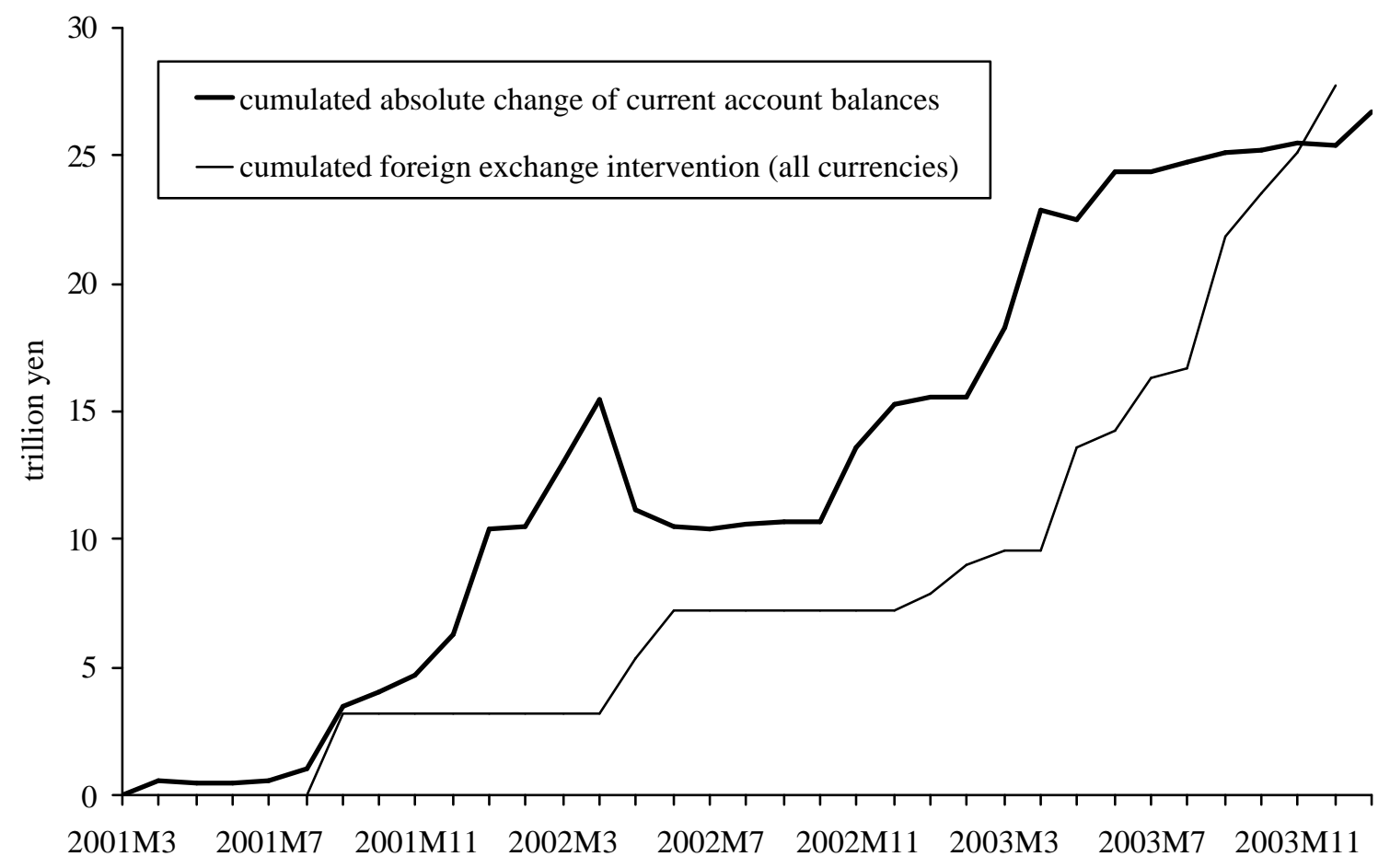

Source: Bank of Japan and Japanese Ministry of Finance. 
Table 1: Descriptive Statistics of the Yen/Dollar and Mark/Dollar Exchange Rates 1991:04-2003:12

\begin{tabular}{lcc}
\hline & yen/dollar & mark/dollar \\
\hline number of observations & 3326 & 3326 \\
Mean & $-8.22 \mathrm{E}-05$ & -9.23 E-06 \\
standard deviation & 0.0068 & 0.0066 \\
Skewness & -0.4822 & -0.0044 \\
Kurtosis & 7.1874 & 5.7316 \\
Jarque-Bera & 3354.68 & 1035.48 \\
\hline
\end{tabular}

Source: IMF: IFS. The German mark represents the euro starting in 1999. 
Table 2: Summary Statistics for Bank of Japan and Federal Reserve Interventions, 1991:04-2003:12

\begin{tabular}{lcc} 
& Bank of Japan & Federal Reserve \\
\hline total intervention days & $297(304)$ & $22(36)$ \\
total transaction volume (billion dollars) & $477.72(487.64)$ & $8.40(17.2)$ \\
percentage of interventions in the yen/dollar market & $97.96 \%$ & $48.83 \%$ \\
unconditional intervention probability & $8.92 \%(9.13 \%)$ & $0.66 \%(1.08 \%)$ \\
\hline number of days with dollar purchases (yen sales) & $264(266)$ & 7.30 \\
total amount of dollar purchases (billions) & 440.02 & 0.41 \\
mean absolute value of dollar purchases (billions) & 1.67 & $4(6)$ \\
\hline number of days with dollar sales (yen purchases) & $33(38)$ & 1.00
\end{tabular}

Source: Japan: Ministry of Finance and Federal Reserve Board. Yen/dollar interventions (interventions against all currencies in brackets). 


\begin{tabular}{lcc}
\hline Constant & Japan & Pooled Intervention \\
& $-1.7992 * * *$ & $-1.7938 * * *$ \\
Yen/dollar returns $r_{t-1}$ & $(-40.1723)$ & $(-44.0123)$ \\
Medium-term deviation $\left(\bar{r}-r_{t}\right)_{t-1}$ & $-33.2257 * * *$ & $-33.0371 * * *$ \\
& $(5.1979)$ & $(5.1863)$ \\
Yen/dollar volatility $\left(r_{t-1}\right)^{2}$ & $-0.0168 * * *$ & $-0.0166 * * *$ \\
& $(0.0030)$ & $(0.0030)$ \\
Intervention Dummy $(\mathbf{t}-1) I_{t-1}^{D}$ & -186.4139 & -186.5031 \\
& $(194.1291)$ & $(194.1067)$ \\
\hline
\end{tabular}


Table 4: Global GARCH Estimation for Equation (1) to (3)

\begin{tabular}{|c|c|c|c|c|c|c|}
\hline & \multicolumn{2}{|c|}{$\begin{array}{l}{[\text { New York 3am (t)] }} \\
\text { Tokyo 5pm (t) }\end{array}$} & \multicolumn{2}{|c|}{$\begin{array}{c}\text { New York Noon }(\mathbf{t}) \\
{[\text { Tokyo } 2 \mathrm{am}(\mathrm{t}+1)]}\end{array}$} & \multicolumn{2}{|c|}{$\begin{array}{l}\text { New York 5pm (t) } \\
{[\text { Tokyo 7am }(t+1)]}\end{array}$} \\
\hline & GARCH & Coefficient & GARCH & Coefficient & GARCH & Coefficient \\
\hline Japan & $(4,6)$ & $\begin{array}{c}?_{1}=.0041(.0014)^{* * *} \\
\mathrm{~b}_{1}=.057(.140)\end{array}$ & $(2,5)$ & $\begin{array}{c}?_{1}=.0009(.0004)^{* *} \\
\mathrm{~b}_{1}=.569(.126)^{* * *}\end{array}$ & $(2,4)$ & $\begin{array}{l}?_{1}=.0010(.0006)^{*} \\
b_{1}=.844(.131)^{* * *}\end{array}$ \\
\hline Japan & $(1,1)$ & $\begin{array}{c}?_{1}=.0007(.0003)^{* * *} \\
\mathrm{~b}_{1}=.088(.089)\end{array}$ & $(1,1)$ & $\begin{array}{c}?_{1}=.0001(.0002) \\
\mathrm{b}_{1}=.567(.107)^{* * *}\end{array}$ & $(1,1)$ & $\begin{array}{c}?_{1}=-.0001(.0001) \\
b_{1}=.872(.105)^{* * *}\end{array}$ \\
\hline Pooled $\dagger$ & $(4,6)$ & $\begin{array}{c}?_{1}=.0045(.0014)^{* * *} \\
\mathrm{~b}_{1}=.0773(.1420)\end{array}$ & $(2,5)$ & $\begin{array}{l}?_{1}=.0010(.0004)^{* * *} \\
b_{1}=.581(.125)^{* * *}\end{array}$ & $(3,4)$ & $\begin{array}{c}?_{1}=.0018(.0003)^{* * *} \\
\mathrm{~b}_{1}=.866(.134)^{* * *}\end{array}$ \\
\hline Pooled $†$ & $(1,1)$ & $\begin{array}{c}?_{1}=.0008(.0003)^{* * *} \\
\mathrm{~b}_{1}=.1071(.0905)\end{array}$ & $(1,1)$ & $\begin{array}{c}?_{1}=.0001(.0002) \\
b_{1}=.586(.106)^{* * *} *\end{array}$ & $(1,1)$ & $\begin{aligned} ?_{1} & =-.0001(.0001) \\
b_{1} & =.890(.104)^{* * *}\end{aligned}$ \\
\hline
\end{tabular}

Heteroskedasticity consistent standard errors according to Bollerslev and Wooldridge (1992). * denotes significance at the 10 percent level. ** denotes significance at the 5 percent level. *** denotes significance at the 1 percent level. $\dagger$ For the Tokyo exchange rate, the Federal Reserve interventions of day $\mathrm{t}-1$ are considered. 
Table 5: Local GARCH Estimation for Equation (1) to (3) - Effect of Pooled Intervention on Yen/Dollar New York Closing Rate by Calendar Years

\begin{tabular}{|c|c|c|c|c|c|c|c|c|c|c|c|c|c|}
\hline & 1991 & 1992 & 1993 & 1994 & 1995 & 1996 & 1997 & 1998 & 1999 & 2000 & 2001 & 2002 & 2003 \\
\hline number of events & 4 & 23 & 49 & 55 & 43 & 5 & 3 & 3 & 12 & 4 & 7 & 7 & 78 \\
\hline total volume (bn. \$) & -0.50 & -5.53 & 23.88 & 20.44 & 53.68 & 15.32 & -8.17 & -23.42 & 62.62 & 28.16 & 26.72 & 32.54 & 177.4 \\
\hline volume per event & -0.13 & -0.24 & 0.49 & 0.37 & 1.25 & 3.06 & -2.72 & -7.81 & 5.22 & 7.04 & 3.82 & 4.65 & 2.27 \\
\hline GARCH specific. (BIC) & $(1,1)$ & $(1,3)$ & $(1,1)$ & $(2,2)$ & $(4,3)$ & $(1,1)$ & $(1,1)$ & $(2,1)$ & $(2,2)$ & $(2,5)$ & $(3,1)$ & $(1,1)$ & $(1,1)$ \\
\hline$\gamma_{1}$ & $\begin{array}{c}-0.059 \\
(0.049)\end{array}$ & $\begin{array}{l}-0.0007 \\
(0.0031)\end{array}$ & $\begin{array}{c}0.0061 * * * \\
(0.0007)\end{array}$ & $\begin{array}{c}0.0104 \\
(0.0071)\end{array}$ & $\begin{array}{c}0.0325^{* * *} \\
(0.0060)\end{array}$ & $\begin{array}{c}-0.0018 * * \\
(0.0007)\end{array}$ & $\begin{array}{c}0.0156 * * * \\
(0.0055)\end{array}$ & $\begin{array}{l}-0.0020 \\
(0.0017)\end{array}$ & $\begin{array}{c}-0.0017 * * * \\
(0.0006)\end{array}$ & $\begin{array}{c}-0.0018 * * \\
(0.0009)\end{array}$ & $\begin{array}{c}-0.0019 * * \\
(0.0009)\end{array}$ & $\begin{array}{l}-0.0020 * \\
(0.0012)\end{array}$ & $\begin{array}{c}-0.0019 * * * \\
(0.00004)\end{array}$ \\
\hline $\mathbf{b}_{1}$ & $\begin{array}{c}-32.34 * * \\
(14.62)\end{array}$ & $\begin{array}{c}4.91 \\
(3.22)\end{array}$ & $\begin{array}{l}-2.95 \\
(2.79)\end{array}$ & $\begin{array}{c}-.0868 \\
(1.6661)\end{array}$ & $\begin{array}{c}1.86^{* * * *} \\
(0.69)\end{array}$ & $\begin{array}{c}0.3602 \\
(0.2992)\end{array}$ & $\begin{array}{c}2.65 * * * \\
(0.95)\end{array}$ & $\begin{array}{c}1.16 \\
(1.70)\end{array}$ & $\begin{array}{c}1.68 * * * \\
(0.16)\end{array}$ & $\begin{array}{c}1.05 * * * \\
(0.29)\end{array}$ & $\begin{array}{l}0.72 * * * \\
(0.2734)\end{array}$ & $\begin{array}{c}0.91 * * \\
(0.3615)\end{array}$ & $\begin{array}{l}0.79 * * * \\
(0.1629)\end{array}$ \\
\hline $\operatorname{GARCH}(\mathbf{1}, \mathbf{1})$ & $(1,1)$ & $(1,1)$ & $(1,1)$ & $(1,1)$ & $(1,1)$ & $(1,1)$ & $(1,1)$ & $(1,1)$ & $(1,1)$ & $(1,1)$ & $(1,1)$ & $(1,1)$ & $(1,1)$ \\
\hline$\gamma_{1}$ & & $\begin{array}{l}-0.0044 \\
(0.0138)\end{array}$ & & $\begin{array}{c}0.00003 \\
(0.003)\end{array}$ & $\begin{array}{c}0.0758 * * \\
(0.0320)\end{array}$ & & & $\begin{array}{c}0.0155 \\
(0.0149)\end{array}$ & $\begin{array}{c}-0.0041 * * \\
(0.0017)\end{array}$ & $\begin{array}{l}-0.0013 \\
(0.0022)\end{array}$ & $\begin{array}{c}0.0015 \\
(0.0092)\end{array}$ & & \\
\hline$b_{1}$ & & $\begin{array}{c}5.12 \\
(3.74)\end{array}$ & & $\begin{array}{c}0.9567 \\
(0.9679)\end{array}$ & $\begin{array}{c}1.87 \\
(1.30)\end{array}$ & & & $\begin{array}{c}1.79 \\
(3.81)\end{array}$ & $\begin{array}{c}2.16^{* * *} \\
(0.32)\end{array}$ & $\begin{array}{c}1.43 * * * \\
(0.43)\end{array}$ & $\begin{array}{c}0.6309 \\
(0.9515\end{array}$ & & \\
\hline
\end{tabular}

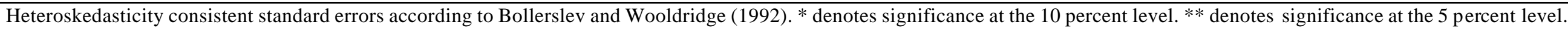
$* * *$ denotes significance at the 1 percent level. 


\begin{tabular}{|c|c|c|c|c|c|c|c|c|c|}
\hline \multirow[t]{2}{*}{ intervention cluster } & $05 / 13 / 91$ & $01 / 17 / 92$ & $04 / 02 / 93$ & $02 / 15 / 94$ & $02 / 17 / 95$ & 11/3/97 & 01/12/99 & 09/17/01 & $01 / 15 / 03$ \\
\hline & 08/19/91 & $08 / 11 / 92$ & $09 / 07 / 93$ & 11/03/94 & $02 / 27 / 96$ & 6/17/98 & 04/03/00 & $06 / 28 / 02$ & 12/31/03 \\
\hline \multirow[t]{2}{*}{ observation period } & 04/01/91 & 11/04/91 & $12 / 08 / 92$ & $12 / 27 / 93$ & $12 / 28 / 94$ & 01/01/97 & $10 / 01 / 98$ & $12 / 26 / 00$ & $01 / 01 / 03$ \\
\hline & 11/01/91 & 12/07/92 & $12 / 24 / 93$ & $12 / 27 / 94$ & $12 / 31 / 96$ & 09/30/98 & $12 / 25 / 00$ & $31 / 12 / 02$ & $31 / 12 / 03$ \\
\hline period number & 1 & 2 & 3 & 4 & 5 & 6 & 7 & 8 & 9 \\
\hline number of events & 4 & 23 & 49 & 55 & 48 & 6 & 16 & 14 & 78 \\
\hline total volume (bn. \$) & -0.50 & -5.53 & 23.88 & 20.44 & 69.00 & -31.58 & 90.42 & 59.26 & 177.4 \\
\hline volume per event & -0.13 & -0.24 & 0.49 & 0.37 & 1.44 & -5.26 & 5.65 & 4.23 & 2.27 \\
\hline GARCH specific. (BIC) & $(1,1)$ & $(1,1)$ & $(1,2)$ & $(3,2)$ & $(2,5)$ & $(1,1)$ & $(1,3)$ & $(1,1)$ & $(1,1)$ \\
\hline \multirow[t]{2}{*}{$\gamma_{1}$} & -0.0128 & $-0.0076 * * *$ & $0.0177 * * *$ & $0.0124 * * *$ & $0.0409 * * *$ & 0.0141 & $-0.0022 * * *$ & $-0.0031 * * *$ & $-0.0019 * * *$ \\
\hline & $(0.0461)$ & $(0.0019)$ & $(0.0054)$ & $(0.0027)$ & $(0.0061)$ & $(0.0138)$ & $(0.0006)$ & $(0.0012)$ & $(0.00004)$ \\
\hline \multirow[t]{2}{*}{$b_{1}$} & $-34.66 * *$ & $4.67 *$ & -3.48 & -0.5971 & 0.5911 & 1.59 & $1.63 * * *$ & $0.7992 * * *$ & $0.7850 * * *$ \\
\hline & $(16.66)$ & $(2.84)$ & $(3.35)$ & $(1.49)$ & $(0.81)$ & $(1.66)$ & $(0.18)$ & $(0.2587)$ & $(0.1629)$ \\
\hline $\operatorname{GARCH}(1,1)$ & $(1,1)$ & $(1,1)$ & $(1,1)$ & $(1,1)$ & $(1,1)$ & $(1,1)$ & $(1,1)$ & $(1,1)$ & $(1,1)$ \\
\hline \multirow{2}{*}{$\gamma_{1}$} & & & $0.0056 * * *$ & 0.0005 & $0.0111 * * *$ & & $-.0017 *$ & & \\
\hline & & & $(0.0011)$ & $(0.0029)$ & $(0.0022)$ & & $(0.0009)$ & & \\
\hline \multirow[t]{2}{*}{$b_{1}$} & & & -3.15 & 0.9243 & $1.69 * * *$ & & $1.79 * * *$ & & \\
\hline & & & $(2.71)$ & $(1.07)$ & $(0.50)$ & & $(0.22)$ & & \\
\hline
\end{tabular}


Table 7: Change-points According to the Kokoszka and Leipus (1999) Detector

\begin{tabular}{lccc}
\hline Date & Number of Observations & Statistic & Probability \\
& & $\sqrt{n} R_{k} / \hat{\sigma}_{\text {VARHAC }}$ & \\
\hline 07-May-1997 & 1592 & 2.2466 & 0.000 \\
03-Apr-2000 & 2350 & 1.4484 & 0.030 \\
20-Sep-2002 & 2994 & 1.4117 & 0.037 \\
\hline
\end{tabular}

New York closing rate. Change points with confidence level 0.95 or higher. 


\begin{tabular}{|c|c|c|c|c|}
\hline intervention period & $\begin{array}{l}04 / 02 / 1991 \\
05 / 07 / 1997\end{array}$ & $\begin{array}{l}\text { 05/08/1997 } \\
04 / 03 / 2000\end{array}$ & $\begin{array}{l}04 / 04 / 2000 \\
09 / 20 / 2002\end{array}$ & $\begin{array}{l}09 / 21 / 2002 \\
12 / 31 / 2003\end{array}$ \\
\hline GARCH specific. (BIC) & $(1,5)$ & $(1,4)$ & $(1,1)$ & $(1,1)$ \\
\hline$?_{1}$ & $\begin{array}{c}0.0389 * * * \\
(0.0025)\end{array}$ & $\begin{array}{c}-0.0028 * * * \\
(0.0007)\end{array}$ & $\begin{array}{c}-0.0024 * * * \\
(0.0004)\end{array}$ & $\begin{array}{c}-0.0023 * * * \\
(0.0007)\end{array}$ \\
\hline$b_{1}$ & $\begin{array}{c}0.291 \\
(0.718)\end{array}$ & $\begin{array}{c}1.456 * * * \\
(0.117)\end{array}$ & $\begin{array}{c}0.727 * * * \\
(0.264)\end{array}$ & $\begin{array}{c}0.854 * * * \\
(0.071)\end{array}$ \\
\hline $\begin{array}{l}\operatorname{GARCH}(1,1) \\
?_{1}\end{array}$ & $\begin{array}{c}0.0086^{* * * *} \\
(0.0013)\end{array}$ & $\begin{array}{c}-0.0018 \\
(0.0014)\end{array}$ & & \\
\hline$b_{1}$ & $\begin{array}{c}0.999 * * * \\
(0.368)\end{array}$ & $\begin{array}{c}1.439 * * * \\
(0.154)\end{array}$ & & \\
\hline
\end{tabular}

New York Closing Rates. 